\title{
Small mammals distribution and diversity in a plague endemic area in West Usambara Mountains, Tanzania
}

NJAKA A. RALAIZAFISOLOARIVONY', DIDAS N. KIMARO ${ }^{*}$, NGANGA I. KIHUPI', LOTH S. MULUNGU², HERWIG LEIRS ${ }^{3,4}$, BALTHAZAR M. MSANYA ${ }^{5}$, JOZEF A. DECKERS ${ }^{6}$ and HUBERT GULINCK ${ }^{6}$

${ }^{1}$ Department of Agricultural Engineering and Land Planning, Sokoine University of Agriculture, P.O. Box 3003, Morogoro, Tanzania

${ }^{2}$ Pest Management Centre, Sokoine University of Agriculture, P. O. Box 3110, Morogoro, Tanzania

${ }^{3}$ University of Antwerp, Evolutionary Ecology Group, Groenenborgerlaan 171, B-2020 Antwerpen, Belgium

${ }^{4}$ Danish Pest Infestation Laboratory, University of Aarhus, Department of Integrated Pest Management, Skovbrynet 14, DK-2800, Kongens Lyngby, Denmark

${ }^{5}$ Department of Soil Science, Sokoine University of Agriculture, P.O. Box 3008, Morogoro, Tanzania

${ }^{6}$ Department of Earth \& Environmental Sciences, University of Leuven, Celestijnenlaan 200 E, B-3001 Heverlee, Belgium

Abstract: Small mammals play a role in plague transmission as hosts in all plague endemic areas. Information on distribution and diversity of small mammals is therefore important for plague surveillance and control in such areas. The objective of this study was to investigate small mammals' diversity and their distribution in plague endemic area in the West Usambara Mountains in north-eastern Tanzania. Landsat images and field surveys were used to select trapping locations in different landscapes. Three landscapes with different habitats were selected for trapping of small mammals. Three types of trap were used in order to maximise the number of species captured. In total, 188 animals and thirteen species were captured in 4,905 trap nights. Praomys delectorum and Mastomys natalensis both reported as plague hosts comprised $50 \%$ of all the animals trapped. Trap success increased with altitude. Species diversity was higher in plantation forest followed by shrub, compared to other habitats, regardless of landscape type. It would therefore seem that chances of plague transmission from small mammals to humans are much higher under shrub, natural and plantation forest habitats.

Keywords: Plague, small mammals, species diversity, distribution, Tanzania

\section{Introduction}

Information on the spatial distribution of small mammals at landscape scale in the West Usambara Mountains is lacking (Neerinckx et al., 2008). This is a bottleneck in the surveillance and in policies concerning this dangerous disease as some of the small mammal species identified in the West Usambara Mountains are considered to be plague hosts (Kilonzo et al., 2005).The Tanzanian Government spends over one million Euros per annum to combat plague outbreaks (Kilonzo et al., 2005). From 1986 through 2003, there were 7800 plague cases and 700 deaths in the West Usambara Mountains, Tanzania (Kilonzo et al., 2003).

It has become clear from a number of studies that environmental factors and their specific locations should be considered in an attempt to explain the outbreaks of plague. Neerinckx et al. (2008) demonstrated that there are significant relationships between plague occurrence and altitude in the West Usambara Mountains. It is reported that the spatial distribution of plague hosts is influenced by a combination of environmental factors, including vegetation habitat, which influence food availability and shelter for small mammals (Mulungu et al., 2011).

The distribution of small mammals in a complex landscape with contrasts in landform, vegetation and land use is not well understood. The studies that have been undertaken so far do not allow the derivation of small mammals-landscape relationship (Laudisoit, 2009). This study therefore attempts to link the distribution of small mammals and indices of species diversity with

\footnotetext{
${ }^{*}$ Correspondence: Didas N. Kimaro; Email: didas kimaro@yahoo.com
} 
landscape characteristics in plague endemic zones in the West Usambara Mountains in northeastern, Tanzania.

\section{Materials and Methods}

\section{Study area}

The study was conducted in a rectangular section between $4^{\circ} 22^{\prime} \mathrm{S}, 38^{\circ} 05^{\prime} \mathrm{E}$ (northwest corner) and $5^{\circ} \mathrm{O} 8^{\prime} \mathrm{S}, 38^{\circ} 38^{\prime} \mathrm{E}$ (southeast corner) in Lushoto District in north-eastern Tanzania from December 2009 to March 2010. The study area ranges in elevation from 300 to $2,250 \mathrm{~m}$. The annual precipitation varies from $600 \mathrm{~mm}$ in the plains up to $2000 \mathrm{~mm}$ in the escarpment and on the plateau. The average annual temperature ranges from $27^{\circ} \mathrm{C}$ down to $17^{\circ} \mathrm{C}$ in a toposequence from 800 to $1800 m$ above sea level. By the time of the plague outbreak period (1980 to 2003) the population density in Lushoto District was 254 persons per $\mathrm{km}^{2}$, making this district one of the most densely populated in Tanzania (NBS, 2003). From west to east the toposequence is characterised by a dry plain with stone rich shallow soils, across an abrupt rock escarpment, ending with an undulating plateau (Neerinckx et al., 2008). Most of the soils are red to black Ferrasols, with a sandy-clay-loam texture, and low pH (Neerinckx, 2006; Laudisoit, 2009). Natural forest reserves (Magamba) and plantation forests (Shume-Nywelo) still cover at least $60 \%$ of the study area, although massive deforestation and conversion to agricultural land started around the 1960 s in the study area.

\section{Identification and mapping of habitats within landscapes}

In total, 67 observations of vegetation categories were made within the study area with about 52 observations done in the plateau, eight in the escarpment and seven in the plain landscape (Figure 1).

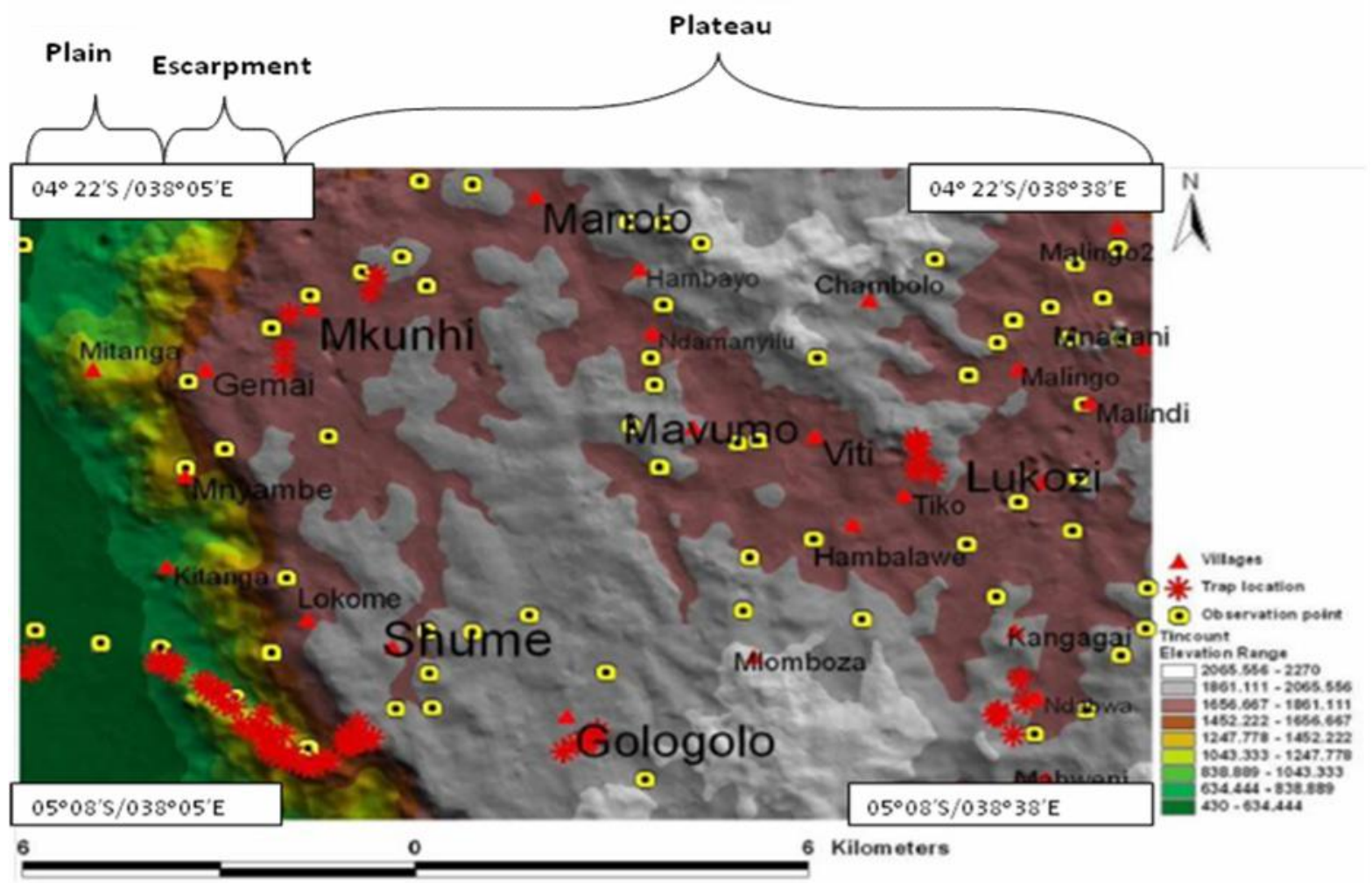

Figure 1: Selected sites for observation points and trapping locations in different landscapes 
Nine habitat types, namely natural-forest, plantation-forest, horticulture, shrub, herbaceous, cultivation (mixed-crops), rockiness, bare-ground (<10\% cover) and human settlement were mapped as top level of differentiation, according to FAO rules (di Gregorio, 2005). The second level involved description of sub-habitats in terms of openness and height of the first dominant layer (strata) of the vegetation (di Gregorio \& Jansen, 1998). Fourteen sub-habitats were identified and these included closed-forest (CT3), open-forest (OT3), closed-shrub (CSh), edge-offorest (Edg Csh), open-shrub (Osh), sparse-shrub (SSh), closed-herbaceous (CHe), closedplantation forest (CT3p), mixed-contour-cultivation ( $\mathrm{mCMz}$ ), 'miraba-cultivation (an indigenous land management practice with grass strips surrounding crop fields) ( $M c M z)$, fallow-cultivation (ScFal), cultivation-without-contour ( $\mathrm{ScMz}$ ), settlements and rocky-habitat.

\section{Small mammals trapping}

Trapping small mammals was executed twice in December 2009 and in March 2010. Three different types of traps (Figure 2a, b and c) were employed in order to trap a variety of small mammal species and reduce bias associated with some traps (Laudisoit, 2009). Traps used included 49 Sherman traps, 20 wire cages and 30 buckets for pitfall traps per habitat. The bait used was a mixture of peanut butter and maize bran for Sherman traps. Roasted maize grains and roasted sardines 'dagaa' were used for wire cage traps. The Sherman traps ( $23 \times 9.5 \times 8 \mathrm{~mm})$ were placed $5 \mathrm{~m}$ apart and pitfall traps made of 10-litre water buckets were set $10 \mathrm{~m}$ apart along a pitfall line. Two trap nights were organised per habitat type. Each trap site was georeferenced by GPS and inspected every morning. Traps having animals were replaced by empty traps.
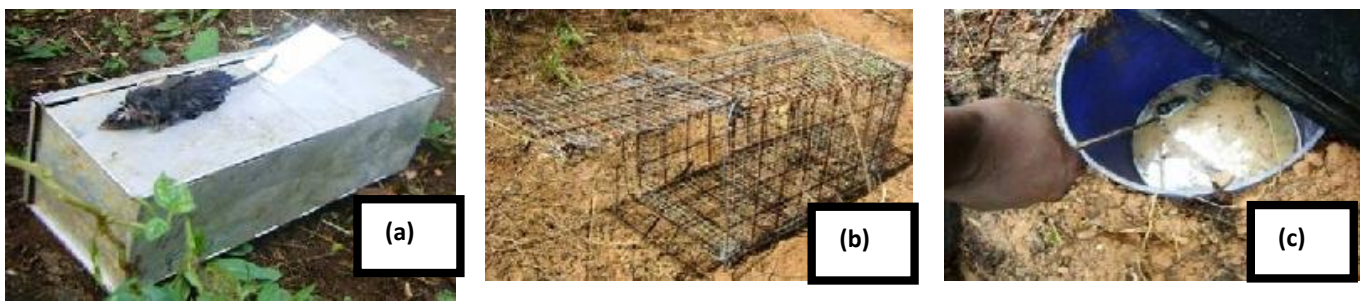

Figure 2: (a) Sherman live trap, (b) live wire cage or spring door trap and (c) bucket used for pitfall trap

Trapped animals were collected early morning and identified to genus level following the established taxonomic nomenclature (Kingdon, 1974; Wilson \& Reeder, 2005), weighed (to nearest gramme), and the state of the vagina (closed or perforated) or position of the testes (scrotal or abdominal) was noted. In addition the following measurements were taken: head and body length, tail, hind foot and ear length (to nearest millimetre) (Nagorsen \& Peterson, 1980). All collected specimens were prepared as scientific voucher specimens in the form of fluid preserved specimen. Initially, the specimens were preserved in $10 \%$ formalin with transfer later to 70\% ethanol. Specimens collected from the study area are currently deposited at Sokoine University of Agriculture, Pest Management Centre, Morogoro, Tanzania.

\section{Data analysis}

The percentage trapped individuals was expressed according to Telford (1989) (Equation 1)

lrap success $=\frac{\mathrm{N}}{\mathrm{Nix} \text { Nn }} \times 100$

where: $\mathrm{N}$ is number of animals trapped; $\mathrm{Nt}$ is number of traps used; $\mathrm{Nn}=$ duration in terms of nights during which the trap was set. Species diversity was estimated using the standard Shannon Wiener index (Equation 2) in order to characterise species diversity and assess for both abundance and evenness of the species in the habitat as:

$H=-\sum_{i=1}^{s}\left(P_{i} \ln P_{i}\right)$

Where: $P_{i}$ is the relative proportion of species $i$ in habitat and $I n$ is the natural logarithm. 


\section{Ethical considerations}

This study received approval from Directorate of Research and Post-Graduate Studies of Sokoine University of Agriculture, Tanzania and Flemish Inter-University Council (VLIR-UOS) of Belgium.

\section{Results}

\section{Trap success}

The trap success ranged from 0.3 to $66.7 \%$ for 4,905 trap nights (Table 1 ). Trap success was significantly different $\left(\mathrm{F}_{5,80}=52.2 ; \mathrm{p}=0.001\right)$ among habitats along the landscapes. Mixed contour cultivation on the plateau had more small mammals than other types of contour cultivation. Results show further that 'miraba' cultivation in the plateau above 1,600 $\mathrm{m}$ had a trap success of $11 \%$, which is much higher than the same habitat at lower altitudes $(<1,000 \mathrm{~m})$ with a trap success of $<4 \%$.

Table 1: Trap success of small mammals in various habitats and different altitudes

\begin{tabular}{|c|c|c|c|c|c|}
\hline Main habitat & Altitude & Sub-habitat & No. of trapped animals & Trap nights & Trap success \\
\hline \multirow{8}{*}{ Natural forest } & $700-1000$ & $\mathrm{CT}_{3}$ & 2 & 224 & 0.9 \\
\hline & $1000-1600$ & $\mathrm{CT}_{3}$ & 1 & 298 & 0.3 \\
\hline & $1600-1900$ & $\mathrm{CT}_{3}$ & 7 & 72 & 9.7 \\
\hline & $1900-2200$ & $\mathrm{CT}_{3}$ & 5 & 29 & 17.2 \\
\hline & Total & $\mathrm{CT}_{3}$ & 15 & 623 & 2.4 \\
\hline & $700-1000$ & OT3 & 2 & 147 & 1.4 \\
\hline & $1900-2200$ & OT3 & 5 & 52 & 9.6 \\
\hline & Total & $\mathrm{OT}_{3}$ & 7 & 299 & 2.3 \\
\hline \multirow{18}{*}{ Shrub } & $400-700$ & CSh & 6 & 425 & 1.4 \\
\hline & $700-1000$ & CSh & 2 & 408 & 0.5 \\
\hline & $1000-1600$ & CSh & 1 & 134 & 0.8 \\
\hline & $1900-2200$ & CSh & 19 & 238 & 8.0 \\
\hline & Total & CSh & 28 & 1205 & 2.3 \\
\hline & $1000-1600$ & Edge CSh & 2 & 3 & 66.7 \\
\hline & $1900-2200$ & Edge CSh & 13 & 203 & 6.4 \\
\hline & Total & Edge CSh & 15 & 206 & 7.3 \\
\hline & $400-700$ & Osh & 7 & 494 & 1.4 \\
\hline & $1000-1600$ & Osh & 3 & 134 & 2.2 \\
\hline & $1600-1900$ & Osh & 16 & 156 & 10.3 \\
\hline & $1900-2200$ & Osh & 23 & 98 & 23.5 \\
\hline & Total & Osh & 49 & 953 & 5.1 \\
\hline & $1000-1600$ & SSh & 4 & 100 & 4.0 \\
\hline & Total & SSh & 4 & 100 & 4.0 \\
\hline & $1000-1600$ & Che & 2 & 200 & 1.0 \\
\hline & $1600-1900$ & Che & 1 & 10 & 10.0 \\
\hline & Total & Che & 3 & 310 & 1.0 \\
\hline \multirow{2}{*}{ Plantation forest } & $1900-2200$ & СТ3р & 20 & 266 & 7.5 \\
\hline & Total & CT3p & 20 & 266 & 7.5 \\
\hline \multirow{2}{*}{ Settlement } & $1900-2200$ & Sset & 1 & 10 & 10.0 \\
\hline & Total & Sset & 1 & 10 & 10.0 \\
\hline \multirow{9}{*}{ Cultivation } & $1600-1900$ & $\mathrm{mCMz}$ & 13 & 64 & 20.3 \\
\hline & Total & $\mathrm{mCMz}$ & 13 & 64 & 20.3 \\
\hline & $1600-1900$ & $M c M z$ & 16 & 400 & 4.0 \\
\hline & $1900-2200$ & $\mathrm{McMz}$ & 7 & 62 & 11.3 \\
\hline & Total & $M c M z$ & 23 & 462 & 5.0 \\
\hline & $1000-1600$ & ScFal & 1 & 40 & 2.5 \\
\hline & Total & ScFal & 1 & 106 & 0.9 \\
\hline & $1600-1900$ & $\mathrm{ScMz}$ & 9 & 180 & 5.0 \\
\hline & Total & $\mathrm{ScMz}$ & 9 & 180 & 5.0 \\
\hline
\end{tabular}

Where: $\mathrm{CT}_{3}=$ closed forest, $\mathrm{OT}_{3}=$ disturbed forest, $\mathrm{CSh}=\mathrm{Closed}$ shrub, Osh= open shrub, $\mathrm{SSh}=\mathrm{sparse}$ shrub, $\mathrm{CH}=$ closed herbaceous, $\mathrm{CT}_{3 \mathrm{P}}=$ closed plantation forest, ESet= very scattered (emergent) settlement, SSet= sparse 
settlement, $\mathrm{mCMz}=$ mix contour cultivation, $\mathrm{McMz}=$ 'Miraba' cultivation, ScMz= cultivation without contour, ScFal= cultivation without contour and in fallow. Trap night= total number of day of traps times the total number of trap used

\section{Species distribution in different landscapes and habitats}

Praomys delectorum was found in almost all landscapes, but mostly in the natural forest, plantation forest and shrub habitats. Xerus erthropus was strictly limited to plain landscapes. Acomys wilson was limited to the plain and the escarpment (Table 2). Xerus erthropus, A. wilson, Helogale parvula and Genetta genetta were only found in the plain landscape while Otomys angoniensis and Aethomys chrysophilus were found mainly on the escarpment. Similarly, Grammomys dolichurus, Luphoromys kilonzoi, Rattus rattus, Mastomys natalensis, Mus munitoides and Crocidura hirta were found on the plateau (Table 2).

Table 2: Distribution of different species of small mammals according to landscapes

\begin{tabular}{|c|c|c|c|c|c|c|c|c|c|c|c|c|}
\hline \multirow[t]{2}{*}{ Species } & \multicolumn{2}{|c|}{ Plain } & \multicolumn{4}{|c|}{ Escarpment } & \multicolumn{6}{|c|}{ Plateau } \\
\hline & NF & $\mathrm{SH}$ & $\mathrm{CU}$ & NF & $\mathrm{HB}$ & $\mathrm{SH}$ & CU & NF & PF & ST & $\mathrm{HB}$ & $\mathrm{SH}$ \\
\hline Praomys delectorum & $\mathrm{x}$ & & & $\mathrm{x}$ & & & & $\mathrm{x}$ & $\mathrm{x}$ & & & $\mathrm{x}$ \\
\hline Xerus erthropus & $x$ & $x$ & & & & & & & & & & \\
\hline Acomys wilson & & $x$ & & & & $\mathrm{x}$ & & & & & & \\
\hline Helogale parvula & & $x$ & & & & & & & & & & \\
\hline Genetta genetta & & $x$ & & & & & & & & & & \\
\hline Otomys angoniensis & & & $x$ & & & & & & & & & \\
\hline Aethomys chrysophilus & & & & $x$ & $x$ & $x$ & & & & & & $x$ \\
\hline Grammomys dolichurus & & & & & & $x$ & $\mathrm{x}$ & $x$ & $x$ & & $\mathrm{x}$ & $\mathrm{x}$ \\
\hline Luphoromys kilonzoi & & & & & & $x$ & $x$ & $x$ & $x$ & & & $x$ \\
\hline Rattus rattus & & & & & & & & & & $\mathrm{X}$ & & $x$ \\
\hline Mastomys natalensis & & & & & & $x$ & $\mathrm{x}$ & & $\mathrm{x}$ & & & $x$ \\
\hline Mus munitoides & & & & & & & $x$ & & $x$ & & & \\
\hline Crocidura hirta & & & & & & & & $\mathrm{x}$ & $x$ & & & $\mathrm{x}$ \\
\hline
\end{tabular}

Table 3: Species diversity within main habitats under Plain and Escarpment landforms

\begin{tabular}{|c|c|c|c|c|}
\hline Landform & Main habitat & Species & No. of animal trapped & Diversity index \\
\hline \multirow[t]{8}{*}{ Plain } & Natural Forest & P. delectorum & 1 & \\
\hline & & X. erthropus & 1 & \\
\hline & & Sub-total & 2 & 0.3 \\
\hline & Shrub & A. wilsoni & 8 & \\
\hline & & H. parvula & 1 & \\
\hline & & G. genetta & 1 & \\
\hline & & X. erthropus & 3 & \\
\hline & & Sub-total & 13 & 0.4 \\
\hline \multirow[t]{13}{*}{ Escarpment } & Cultivation & O. angoniensis & 1 & 0.0 \\
\hline & & Sub-total & 1 & \\
\hline & Natural Forest & A. chrysophilus & 2 & \\
\hline & & P. delectorum & 1 & \\
\hline & & Sub-total & 3 & 0.3 \\
\hline & Herbaceous & A. chrysophilus & 2 & \\
\hline & & Sub-total & 2 & 0.0 \\
\hline & Shrub & A. wilsoni & 1 & \\
\hline & & A. chrysophilus & 6 & \\
\hline & & G. dolichurus & 1 & \\
\hline & & L. kilonzoi & 1 & \\
\hline & & M. natalensis & 1 & \\
\hline & & Sub-total & 10 & 0.5 \\
\hline
\end{tabular}

\section{Small mammal species diversity}

Species richness varied with landscape and habitat type. In the plateau, the highest number of species was found in the shrubs followed by plantation forest whereas the lowest number was 
found in herbaceous cover with G. dolichurus or A. chrysophilus as characteristic species (Table 3). The plain had two types of habitat with diversity indices of 0.3 and 0.45 for natural forest and shrub respectively. Dominant small mammal species in the natural forest habitat were $P$. delectorum and $X$. erthropus while shrub habitat hosted $A$. wilsoni, $H$. parvula, G. genetta and Squirrel spp. The $A$. wilsoni and two species of Squirrel were dominant species in the plain comprising $85 \%$ of the trapped species.

On the escarpment, results show that shrub habitat had higher species diversity than other habitats with $A$. chrysophlilus and $P$. delectorum comprising $60 \%$ of trapped small mammals. Rodent species diversity in the plateau landscape is also presented in Table 3 . Results show that plantation forest and shrub habitats had the highest species diversity index of $>0.5$. The dominant species were Grammomys spp., L. kilonzoi and P. delectorum. Natural forest had species diversity index of 0.44 , whereas cultivation had the least species diversity index (Table 4 ).

Table 4: Species diversity within main habitats under Plateau landforms

\begin{tabular}{|c|c|c|c|c|}
\hline \multirow{30}{*}{ Plateau } & \multirow{5}{*}{ Cultivation } & G. dolichurus & 4 & \\
\hline & & L. kilonzoi & 2 & \\
\hline & & M. natalensis & 37 & \\
\hline & & M. minutoides & 2 & \\
\hline & & Sub-total & 45 & 0.3 \\
\hline & \multirow{5}{*}{ Natural Forest } & C. hirta. & 1 & \\
\hline & & G. dolichurus & 2 & \\
\hline & & L. kilonzoi & 3 & \\
\hline & & P. delectorum & 11 & \\
\hline & & Sub-total & 17 & 0.4 \\
\hline & \multirow{7}{*}{ Plantation forest } & C. hirta & 2 & \\
\hline & & G. dolichurus & 3 & \\
\hline & & L. kilonzoi & 4 & \\
\hline & & M. natalensis & 3 & \\
\hline & & M. minutoides & 1 & \\
\hline & & P. delectorum & 7 & \\
\hline & & Sub-total & 20 & 0.7 \\
\hline & \multirow{2}{*}{ Settlement } & R. rattus & 1 & \\
\hline & & Total & 1 & 0.0 \\
\hline & \multirow{2}{*}{ Herbaceous } & G. dolichurus & 1 & \\
\hline & & Sub-total & 1 & 0.0 \\
\hline & \multirow{10}{*}{ Shrub } & A. chrysophilus & 1 & \\
\hline & & C. hirta & 2 & \\
\hline & & G. dolichurus & 14 & \\
\hline & & L. kilonzoi & 19 & \\
\hline & & M. natalensis & 1 & \\
\hline & & M. minutoides & 1 & \\
\hline & & P. delectorum & 34 & \\
\hline & & R. rattus & 1 & \\
\hline & & Sub-total & 73 & 0.6 \\
\hline & & Total & 188 & \\
\hline
\end{tabular}

\section{Discussion}

Plague is a rare bacterial disease caused by Yersinia pestis. Plague has been endemic in Tanzania for more than a century (Kilonzo et al., 2005). It has been reported that several rodent species and their associated flea complexes are maintenance (enzootic) hosts for plague and form the basis of epidemic foci in plague endemic areas. It has been reported that $M$. natalensis is the major reservoir of the disease and is responsible for maintaining and passing the infection to the Rattus rattus, and to humans (Makundi et al., 2003) and P. delectorum (Haule et al., 2013). Similarly, other rodent species such as Arvicanthis nairobae, Lemniscomys striatus, Lophuromys spp., Pelomys fallax, Grammomys dolichurus, Otomys spp., and Rattus rattus, have been 
mentioned for plague maintenance in the area (Kilonzo et al., 2005). Findings from the current study are consistent with these reports. Results also indicate that the diversity of small mammals was higher in the plateau landscape, the most typical plague endemic area in the region (Neerinckx et al., 2008).

These results imply that an increase in elevation is accompanied by concurrent increase in small mammals, both in number and diversity due to increased water and food availability (Hamilton, 1998). Bayessa (2010) indicated that modified habitats including plantation forest and cultivation influenced rodent distribution due to availability and quality of food, shelter and rainfall. Also, results show that the dominant species in the natural forest and in cultivation habitats were $M$. natalensis and $P$. delectorum. The presence of $M$. natalensis in the habitat is consistent with results by Makundi et al. (2008) who reported similar species in deforested habitats at higher elevations of the plateau in the West Usambara Mountains. Praomys delectorum was more common in the plantation forest. The dominant species in shrub habitats were $P$. delectorum, L. kilonzoi and Grammomys spp. comprising the majority of the trapped species. Grammomys were trapped at the interface of closed and open shrub. This is similar to the results by Matlack et al. (2008) who indicated that some rodent species prefer edge corridors. In contrast, a decrease of small mammals with elevation has been reported under Mediterranean climate. This was attributed to a decrease in food availability and increasing dryness and cool weather conditions (Corominas, 2004).

Results further show that different species of small mammals occurred independently in different habitats and landscapes. Similar observations have been reported by Linzey \& Kesner (1997) in Kenya, South Africa, Angola, and Namibia. For example, the results from the current study show that small mammals found in both natural and plantation-forest include $A$. chrysophilus, G. dolichurus, L. kilonzoi, P. delectorum, Crocidura hirta, M. minutoides and X. erthropus. In the plateau landscape, $P$. delectorum comprises $60 \%$ of trapped small mammal's species. Similar results were reported by Stanley \& Goodman (2000) for Gonja Forest Reserve in Tanzania.

It has been demonstrated in the current study that in both plateau and escarpment landscapes, shrubs support more small mammals species than other habitats, including $L$. kilonzoi, P. delectorum, G. dolichurus, M. minutoides, all of which have been reported as plague hosts (Kilonzo et al., 2005; Laudisoit, 2009). This suggests that shrub, natural and plantation forest provide relatively "better" habitats for plague hosts. Therefore, the current results indicate the possibility for plague transmission from small mammals to humans in shrubs, natural and plantation habitats. It is likely therefore that both plateau and escarpment landscapes have potential hosts for plague transmission through interaction between plague hosts and humans (Duplantier et al., 2005). Similarly, it was shown in this study that the escarpment acts like an interface between the plain and the plateau, a place where small mammal species from both landforms intermix. Further research on the relationship between vegetation types and small mammals particularly microclimate of habitats vis-à-vis plague hotspot areas is recommended.

\section{Acknowledgements}

This work was supported by the SUA-VLIR Own Initiative Project - 'Landscape-Ecological Clarification of Bubonic Plague Distribution and Outbreaks in the Western Usambara Mountains, Tanzania' (Acronym: LEPUS), financed by the Flemish Interuniversity Council, Belgium. The authors greatly appreciate the cooperation of many people in Lushoto District and of the Sebastian Kolowa Memorial University who in one way or another facilitated the accomplishment of this work. 


\section{References}

Alpin K.P., Brown, P.R., Jacob, J., Krebs, J.C. \& Singleton, G.R. (2003) Field Methods for Rodents Studies in Asia and the Indo-Pacific. Australian Centre for International Agriculture Research (ACIAR) Monograph No. 100, Canberra, Australia. 223pp.

Bayessa, D. (2010) Species composition, distribution, abundance and habitat association of rodents in forest and farmlands around Tepi, southwest Ethiopia. MSc Dissertation, Addis Ababa University, Ethiopia, 79pp.

Corominas, T.I. (2004) Distribution, population dynamics and habitat selection of small mammals in Mediterranean environments: the role of climate, vegetation structure, and predation risk. http://www.tesisenxarxa.net/. Site visited on 20 April 2009.

Corti, M., Castiglia, R., Colangelo, P., Capanna, E., Beolchini, F., Bekele, A., Oguge, N. O., Makundi, R.H., Sichilima, A.M., Leirs, H., Verheyen, W. \& Verhagen, R. (2005) Cytotaxonomy of rodent species from Ethiopia, Kenya, Tanzania and Zambia. Belgium Journal of Zoology 135, 197-216.

Davis, S. (1998) Effects of Prescribed Fire on Small Mammals and Beetle Assemblages in Conservation Reserve Program (CRP) grasslands. PhD Thesis, Faculty of Texas Technology University. 164pp.

Di Gregorio, A. (2005) Land Cover Classification System: Classification Concepts and User Manual. Food and Agriculture Organization of the United Nations, Rome.

Doggart, N., Cunneyworth, P., Dilger, M.S. \& Fanning, E. (1999) Kwamgumi Forest Reserve, a Biodiversity Survey. East Usambara catchment forest project technical paper No. 40, Dar es Salaam, Tanzania. 92pp.

Duplantier, J.M., Duchemin, J.B., Chanteau, S. \& Carniel, E. (2005) From the recent lessons of the Malagasy foci towards a global understanding of the factors involved in plague reemergence. Veterinary Research 36, 437-453.

Hamilton, A. (1998) Vegetation, climate and soil: altitudinal relationships on the East Usambara Mountains, Tanzania. Journal of East African Natural History 87, 85-89.

Haule, M., Lyamuya, E.E., Hang'ombe, B.M., Kilonzo, B.S. \& Matee, M.I. (2013) Investigation of fleas as vectors in the transmission of plague during a quiescent period in North-Eastern, Tanzania. Journal of Entomology and Nematology 5, 88-93.

Hubalek, Z. (2000) Measures of species diversity in ecology: an evaluation. Folia Zoologica 49, 241260.

Kilonzo, B., Mhina, J., Sabuni, C. \& Mgode, G. (2005) The role of rodents and small carnivores in plague endemicity in Tanzania. Sokoine University of Agriculture, Morogoro, Tanzania. Belgium Journal Zoology 135, 119-125.

Kilonzo, B.S., Lwihula, G.K., Kwesigabo, G. \& Lyamuya, E.F. (2003) Interim Report of Ecosystem Health Project on Plague (Tanzania) for the Period January 2002-January 2003. Ecosystem Health Project, Tanzania. 37pp.

Kingdon, J. (1974) East African Mammals: an Atlas of Evolution in Africa. Academic Press London 2, 343-704.

Laudisoit, A. (2009) Diversity, ecology and status of potential hosts and vectors of the plague bacillus, Yersinia pestis. Contribution to plague epidemiology in an endemic plague focus: the Lushoto District (Tanzania). PhD Thesis, Universiteit Antwerpen, 252pp.

Linzey, A.V. \& Kesner, M.H. (1997) Small mammals of a woodland-savanna ecosystem in Zimbabwe. I. Density and habitat occupancy patterns. Journal of Zoology 243,137-152.

Makundi, R.H., Kilonzo, B.S. \& Massawe, A.P. (2003) Interaction between rodent species in agroforestry habitats in the western Usambara Mountains, north-eastern Tanzania, and its potential for plague transmission to humans. In: Singleton, G.R., L.A. Hinds, C.J. Krebs \& D.M. Spratt (eds), Rats, Mice and People. Australian Centre for International Agricultural Research, Canberra : 20-24. 
Makundi, R.H., Massawe, A.W., Mulungu, L.S., Katakweba, A., Mbise, T.J. \& Mgode, G. (2008) Potential mammalian reservoirs in a bubonic plague outbreak focus in Mbulu District, northern Tanzania, in 2007. Mammalia 72, $253-257$.

Matlack, R.S., Kaufman D.W. \& Kaufman, G.A. (2008) Influence of woody vegetation on small mammals in tallgrass prairie. American Midland Naturalist Journal 160, 7 - 19.

Mulungu, L.S., Mahlaba, T.A., Massawe, A.W., Kennis, J., Crauwels, D., Eiseb, S., Monadjem, A., Makundi, R.H., Katakweba, A.A.S., Leirs, H. \& Belmain, S.R. (2011) Dietary differences of the multimammate mouse, Mastomys natalensins (Smith, 1834), across different habitats and seasons in Tanzania and Swaziland. Wildlife Research 38, 640-646.

Neerinckx, S.B., Peterson, A.T., Gulinck, H., Deckers, J. \& Leirs, H. (2008) Geographic distribution and exological niche of plague in sub-Saharan Africa. International Journal of Health Geographics 7, 1-12.

Neerinckx, S.B. (2006) Ecological factors influencing the spread of plague disease, Lushoto, Tanzania. MSc Thesis. Katholieke Universiteit Leuven. 89pp.

Remis, M. (1997) Western lowland gorilla (Gorilla gorilla) as seasonal frugivores: use of variable resources. American Journal of Primatology 43, 87 - 109.

Stanley, W.T. \& Goodman, S.M (2000) A survey of the small mammals of the Gonja Forest Reserve, Tanzania. Journal of East African Natural History 89, 73-83.

Stanley, W.T. (2005) Small mammals collected in the Udzungwa Mountains National Park, Tanzania. Journal of East African Natural History 94, 203-212. 